\title{
Allocation of Foreign Direct Investment across Brazilian States
}

\author{
Maurício Mesquita Bortoluzzo \\ Professor - Insper - Instituto de Ensino e Pesquisa \\ Endereço para contato: Rua Quatá, 300 - São Paulo \\ CEP: 04546-042 - E-mail: mauriciomb2@insper.edu.br
}

\section{Sergio Naruhiko Sakurai}

Professor - Departamento de Economia (FEARP-USP)

Endereço para contato: Avenida Bandeirantes, 3900 - Ribeirão Preto - SP

CEP: 14040-905 - E-mail: sakurai@usp.br

\section{Adriana Bruscato Bortoluzzo}

Professora - Insper - Instituto de Ensino e Pesquisa

Endereço para contato: Rua Quatá, 300 - São Paulo

CEP: 04546-042 -E-mail: adrianab@insper.edu.br

Recebido em 10 de abril de 2012. Aceito em 29 de janeiro de 2013.

\begin{abstract}
Foreign direct investment (FDI) has become increasingly important for the Brazilian economy: the ratio of FDI inflow to the country's gross domestic product (GDP) increased from a $0.6 \%$ average in the 1980 's to $2.5 \%$ from 2001 to 2010 , according to data from UNCTAD. However, there is great inequality in the distribution of this investment among Brazilian federation units. This study aims at investigating the determining factors for the location of foreign direct investment across Brazilian states, based on an econometric study with panel data for the years 1995, 2000 and 2005. The results showed that foreign investment responded positively to consumer market size, quality of labor and transport infrastructure, but negatively to cost of labor and tax burden.
\end{abstract}

\section{Keywords}

foreign direct investment, panel data, Brazilian states

\section{Jel Classification}

F 21, C23, R12

\section{Resumo}

O Investimento Direto Externo (IDE) tem se tornado cada vez mais relevante para a economia brasileira. A razão do fluxo de IDE sobre o PIB do país subiu de uma média

- The authors would like to thank financial support provided by Capes and Fapesp. Comments from Alex Luiz Ferreira, Bruno de Paula Rocha and two anonymous referees are highly acknowledged. 
de $0,6 \%$ na década de 1980 para 2,5\% de 2001 a 2009, segundo dados da UNCTAD. Observa-se, contudo, uma grande iniquidade na distribuição deste investimento entre as unidades federativas brasileiras. O presente trabalho faz uma investigação sobre os fatores determinantes da localização do Investimento Direto Externo entre estados brasileiros, por meio de um estudo econométrico de dados em painel para os anos de 1995, 2000 e 2005. Os resultados apontam que os investimentos respondem positivamente ao tamanho do mercado consumidor, à qualidade de força de trabalho, à infraestrutura de transporte, mas negativamente ao custo de mão de obra e à carga tributária.

\section{Palavras-Chave}

investimento direto externo, dados em painel, estados brasileiros

\section{Introduction}

International investments are classified as either foreign portfolio investment or foreign direct investment (FDI). Portfolio investments, as the name suggests, correspond to the entry of funds due to investors making purchases in the stock and bond markets, sometimes for speculation, which do not result in ownership or legal control of the company receiving the resources but rather form a portfolio. Conversely, FDI is an investment to exercise or acquire control in an enterprise operating in a country other than that of the investor, with participation in the company management.

Several theoretical models that attempt to explain long-term economic growth agree that saving and investment rates and capital productivity, including human capital, are important factors for determining a sustained GDP growth. FDI can affect product growth rates directly by increasing saving rates and indirectly by increasing capital productivity by means of transferring technology and training the workforce in the recipient country, a phenomenon known in the literature as technology spillover. In Brazil, FDI has been growing in importance. According to data from the Central Bank of Brazil (Banco Central do Brasil, BC), from January 2008 to August 2011, while the balance of current transactions showed a 133.6 billion dollar accumulated deficit, FDI exhibited a 163.5 billion dollar surplus, helping to alleviate the need to finance the Brazilian balance of payments. Moreover, the ratio of FDI inflows to the country's GDP increased from a $0.6 \%$ average in the 1980 's to $1.9 \%$ in the 1990 's and 2.5\% from 2001 to 2010 (Source: UNCTAD). 
The main contribution of this paper comes from an important assessment. While several empirical studies have evaluated the relevant factors in the decision by multinational companies as to which country to select for productive investment, little has been done to establish the determining factors of the location of investment within a country, i.e., to investigate the determining factors of FDI location across the regions in a country. In other words, once a foreign company has chosen the Brazilian economy to invest, which specific region will receive it? Providing answers to this question - which has not been addressed by any other study yet, thus representing the main contribution of this paper - is particularly important for the Brazilian case, given there is a great inequality in the distribution of FDI across states: while Sergipe had a FDI/GDP of $0.8 \%$ in 2005, Rio de Janeiro had a $61 \%$ ratio in the same year, for instance.

Aiming at providing answers for this specific question, this panel data econometric study was designed to analyze the determining factors of FDI distribution across the 27 federation units (FU's) in Brazil. The study was conducted based on the Census of Foreign Capitals in the Country (Censo de Capitais Estrangeiros no País, CCEP) by the BC for the base years 1995, 2000 and 2005, the only years for which data are available - the investigation of this database is another contribution of this paper, as only few studies have examined it. The results showed that investment responded positively to consumer market size, quality of the workforce and transport infrastructure, but negatively to cost of labor and tax burden. In this sense, the significant structural differences across Brazilian states explain the high inequality in the distribution of FDI over the territory.

The paper is organized as follows: In section 2, the theoretical and empirical studies of FDI are reviewed, focusing on the discussion of the aspects that affect the decisions by multinational companies as to the location of their investment. Section 3, in turn, describes the database and the econometric methodology adopted. The results are analyzed in section 4 , and finally, section 5 is the conclusion to the study. 


\section{Literature Review}

The main theoretical foundations regarding the determinants of FDI were developed during the 60's. Previously, however, important theoretical discussion had been already presented by Ohlin (1933), who argued that direct investments in foreign markets were important in order to guarantee access to the supply of inputs, to overcome barriers to trade as well as to explore higher rates of return in growing economies.

Hymer (1960) examined FDI based on industrial organization theory, explaining the expansion of firms as a way to maintain or increase their monopoly power by exploiting market failures. According to the author, companies live in an environment of international competition, and the decision to invest in another country is primarily based on the company's competitive advantages. Because international companies lack in-depth knowledge of local customs and laws, these competitive advantages must be sufficient to overcome the obstacles encountered in the process of setting up a factory in a foreign country.

As a second theoretical viewpoint, Vernon (1966) developed the product cycle model. According to this approach, companies exhibiting competitive advantages in innovation would, at first, start the production locally in order to satisfy the domestic market and, in a second step, to satisfy foreign markets with similar demand traits. In a final stage, when the production reached the maturity (when the interaction among companies reaches high levels of competition, for instance), companies would start the production in other countries, so as to explore cost and trade tariffs reductions, for instance. In this sense, the model suggests that FDI is related to the maturity of trade among countries.

Some years later, Buckley \& Casson (1976) and Buckley \& Casson (1981) proposed a different theory to understand the flows of FDI. In particular, they argue that the market of intermediate products (which include proprietary assets such as copyrights, for instance) is imperfect, exhibiting significant transaction costs especially if the management is performed by different companies. Thus, the integration of markets via FDI and the development of international networks of production might reduce these production costs. Finally, as a fourth theory, Dunning (1981) proposed the so-called eclectic fra- 
mework, which argues that multinational companies promote foreign investment for at least one of the following reasons: the search for natural resources, the search for markets, the search for efficiency and the search for strategic assets or capabilities. More specifically, the theory proposes that foreign companies are potentially able to explore the ownership of specific tangible and non-tangible assets against local companies, which would lead them to explore (i.e., internalize) these assets instead of selling them at the local market. In this case, companies would choose to start the production in a foreign country only if locational advantages were significant enough.

Following these first references, other recent studies have aimed at providing additional theoretical foundations to understand foreign investments. Moosa (2002), for instance, suggested the existence of FDI for expansionist purposes, which explore the specific monopolistic advantages of the firm, and FDI for defensive purposes, which seek to lower production costs. Chakrabarti (2003) combined the theory of international trade under imperfect competition with the literature on the organizational strategy of multinationals to create a structural model that evaluates the role of several potential determinants on the spatial location of FDI. Du, Lu \& Tao (2008), in turn, discussed the benefits of the agglomeration of firms as another important determinant of FDI, separating agglomeration into two types: vertical and horizontal. Vertical agglomeration refers to the existence of companies related to the production chain of the foreign capital enterprise (FCE), i.e., the existence of input suppliers, distributors and customers in the FCE sector. Horizontal agglomeration occurs when there are several companies in the same sector, in the same region. Finally, Konrad \& Kovenock (2009) studied the dynamics of the trade-off faced by countries between attracting new foreign direct investment and extracting tax revenue from existing investments using a model with a discrete time and infinite horizon.

In an empirical perspective, most studies have focused on the determinants of FDI across countries. Euh \& Min (1986) empirically analyzed the FDI of fifty Korean multinationals via a survey conducted in 1984, to conclude that the investment in foreign countries was induced by the need of avoiding restrictions of importing quotas, to export to other countries and to decrease production costs by exploiting cheaper labor workforce abroad. Additionally, social and political stability, the availability of raw materials, growth potential of the local economy and macroeconomic factors, such as inflation 
and exchange rate, were important determinants explaining foreign investments. Nunnenkamp \& Spatz (2002), in turn, conducted a study from a sample of 28 developing countries for the 1987-2000 periods to find significant correlations between FDI and the following variables: GDP per capita, risk factors, years of education, restrictions to foreign trade, complementary factors of production, administrative bottlenecks and cost factors. Workforce endowment is also emphasized by the results provided by Blonigen, Davies \& Head (2003), who explored a panel of countries between 1982 and 1992 to conclude that FDI decreases differences in skilled-labor abundance (between parent and host countries) widen.

Using a panel database of bilateral FDI flows, Bevan \& Saul (2004) studied European Union (EU) inflows targeted to central and western European countries. The authors found that FDI was positively correlated with GDP in both of the countries (origin and destination) and negatively correlated with the distance between them. Based on panel data for 33 countries over the 1985-2000 period, Nonnenberg \& Mendonça (2005) estimated the main determinants of FDI in developing countries and found factors such as GDP size and growth rate, qualification of the workforce and receptiveness to foreign capital (measured by the degree of economic freedom) as the main determinants of FDI inflow, while country risk repelled investment. In the absence of country risk ratings, economic stability (measured by low inflation) significantly influenced the investment attraction. The study also found that a good performance of capital markets in developed economies is a strong determinant of FDI outflows.

By estimating a panel for 15 emerging economies throughout the world for the 1987-2001 periods, Amal \& Seabra (2007) found evidence that the variation of FDI was significantly influenced by the total trade flows of FDI recipient countries, the country's political risk, the degree of economic freedom and the insertion of the recipient country into regional integration processes. Moreover, an analysis of FDI inflows to seven Latin American countries over the 1984-2001 period indicated real exchange rate and, again, political risk, economic freedom and regional integration, as determinants of FDI. Results found by Forssbaeck \& Oxelheim (2008) indicated that financial characteristics of multinationals, in addition to their size and ownership of intangible assets, were important determinants for the decision to invest abroad. Regarding the destination country of 
investment, market size (measured based on the GDP) was a factor in attracting FDI, while high salaries and taxes repelled investment. Rasciute \& Pentecost (2010), in turn, examined the determinants of FDI location in 13 central and eastern European countries from 1997 to 2007, whose results showed that the firm's decision about which country should receive investment varied among sectors and according to the firm's characteristics, such as size and profitability. Finally, focusing on transaction costs related to the need for interaction in real time, Stein \& Daude (2007) made use of data regarding bilateral FDI to find that differences in time zones have caused a negative and increasing effect on the location of FDI, even considering the introduction of new information technologies - time zones also have a negative effect on trade, but this effect is smaller than that on FDI.

As a first reference specifically discussing the distribution of FDI within a country, Coughlin, Terza \& Arromdee (1991), estimated a conditional logit model in order to investigate the location decision of foreign firms investing in manufacturing facilities in the United States, between 1981 and 1983. Their results indicate that states with higher per capita income, higher densities of manufacturing activity, more extensive transportation infrastructure, higher unemployment and lower wages and taxes attracted relatively more foreign investment. Surprisingly, higher unionization rates were associated with increased FDI. As a second reference, Guimarães, Figueiredo \& Woodward (2000) studied the distribution of FDI across Portuguese councils (municipalities) based on a multinomial logit model. Their results suggest the pre-existence of economic activity as the main FDI determinant, in addition to other factors, such as travel time to major cities.

There are also important contributions with regard to China, especially because it has been the world's largest FDI recipient over the recent decades. Broadman \& Sun (1997), for example, identified GDP, transport infrastructure, quality of the workforce and geographical location (coastal region) as important factors for attracting FDI to provinces. Moreover, Fung, Iizaka \& Parker (2002) examined the determinants of direct investment from Japan and the United States to China from 1991 to 1997 and compared the results with determinants of investment from Hong Kong and Taiwan. Local market size (measured based on the GDP) was important for all of the sources, especially from the United States and Japan. The quality 
of the workforce had a significant influence on attracting American and Japanese FDI but, on the contrary, the quality of infrastructure was more important in determining investment from Hong Kong and Taiwan, most likely because they are predominantly exporting countries.

Sun, Tong \& Yu (2002) analyzed panel data for 30 Chinese provinces from 1986-1998. The factors that attracted FDI were the GDP, the quality of the workforce and good infrastructure in the province (measured as the mileage of roads and railways per $\mathrm{km}^{2}$ ), while higher wages and agglomeration repelled investment. Cheng \& Kwan (2000) estimated FDI determinants for 29 Chinese regions by means of a dynamic panel from 1985-1995 and found positive correlations with FDI for the regional market, infrastructure and preferential policy, while the cost of labor was negatively correlated with FDI. In a similar study, Hsiao \& Shen (2003) used panel data for 31 regions of China from 1996-1998 and found infrastructure development and ease of access to a market as key determinants of FDI, in addition to cost and quality of labor.

Specifically concerning the Brazilian case, the FDI inflows have been addressed by different perspectives. Laplane \& Sarti (1997), for instance, emphasize the sectoral reallocation of FDI over the 90's, as the participation of services increased at the same time that the share of the industrial sector suffered a reduction. This is in line with more recent evidence provided by Fernandes \& Campos (2008), who explored the CCEP data to find that sectors receiving the largest amount of FDI in Brazil were not those responding for the larger share of exports - in particular, foreign investments have caused the opposite effect, i.e., have been allocated to import-oriented sectors.

In a different perspective, Silva, Almeida \& Oliveira (2007) analyzed the border effect (which measures the domestic trade bias relatively to international trade) comparing Brazilian states domestic trade with international trade for the year of 1999. Even though the reduction of international barriers to trade over the last years, the results indicate that interstate exports in Brazil were between 33 and 38 times greater than those to other countries, i.e., Brazilian states export much more to other states than to other countries in the world. In particular, exports to a given state were greater for states with a higher GDP, while longer distances resulted in lower exports. The important conclusion provided by the authors is that 
the high participation of domestic transactions on the total trade performed by Brazilian states evidence the significant economic and structural disparities among different regions of the country. As will be further discussed, our results suggest that these regional disparities are likely to affect the allocation of foreign investments across Brazilian states as well. Finally, in a macroeconomic perspective, Mattos, Cassuce \& Campos (2007) applied a vector-error correction model for the 1980-2004 period to find evidence that risk is a key variable, as it exerted negative and very strong influence on the amount of FDI received by the Brazilian economy as a whole. Their results also suggest that FDI was highly sensitive to openness and inflation, but conversely, the influence of exchange rate and domestic economic growth were limited during the period investigated.

According to these references concerning the Brazilian case, it is possible to observe that foreign investment have been addressed by different perspectives, but studies focusing the specific question of how structural and economic conditions influence the regional distribution of FDI are still absent. As previously mentioned, the discussion of this topic is the main contribution of this paper, especially because the significant disparity in the spatial distribution of foreign investment is associated with strong economic and structural inequalities over the territory. Next section provides a deeper description of the figures.

\section{Methodology}

The main source of data used in this study was the Census of Foreign Capitals in the Country (Censo de Capitais Estrangeiros no País, CCEP), conducted by the BC - in particular, currently available censuses, referring to 1995, 2000 and 2005 years, were used. More specifically, companies participating in CCEP were those attracting foreign credit and/or recipients of foreign direct or indirect investment, with direct or indirect participation of non-residents in the company's capital (i) of at least $10 \%$ in shares or shares with voting rights or (ii) of $20 \%$ direct or indirect participation in the total capital. Because the BC does not regard intra-group loans as FDI, these values were obtained from the consolidated balance sheet for each state in the CCEP using the IMF criterion as a measurement of FDI, 
which is internationally accepted - in practice, the BC most likely underestimates FDI stock in Brazil.

The dependent variable was measured based on the existing FDI stock on the last day of the year. Using FDI stock as a dependent variable is consistent with several empirical studies, such as those by Stein \& Daude (2007), Blonigen, Davies \& Head (2003), and Cheng \& Kwan (2000). The values are measured in Reais ( $R$ ), updated by the GDP deflator for the year 2009.

Although theoretical models for FDI determinants have been developed to determine the location of investment among different countries, some variables also differ among different regions of a given country, particularly in the case of Brazil, which has continental dimensions.

According to the literature, an increase of the local market size leads to an increase of FDI by increasing domestic demand, given that one of the reasons for foreign investment is to secure a share of the local consumer market. Three proxies were used to measure market size: the population or number of inhabitants in the state, the relative GDP and a dummy for proximity to the main consumer market, which assumes one for the states of SP, RJ and MG and zero for all of the other states. The number of inhabitants and GDP of each state were obtained from the censuses conducted by the Brazilian Institute of Geography and Statistics (Instituto Brasileiro de Geografia e Estatística, IBGE). The GDP figures have been updated using the GDP deflator to Reais for the year 2009 and the relative GDP, used as one of the proxies for market size, is defined as the FU GDP divided by the country GDP - for each census year, the arithmetic average of the previous five years was calculated, including the base year. ${ }^{1}$

It is expected that the better the quality of human capital, the greater the efficiency in production, which would thus attract FDI. In order to capture this effect, the illiteracy rate for individuals aged 15 years and older was used as a proxy for the quality of human capital, based on the National Household Sample Survey (Pesquisa Nacional por Amostra de Domicílios, PNAD); in particular, for the year 2000,

${ }^{1}$ For the 2000 Census, for example, the simple arithmetic average of the relative GDP for the state was calculated for the years 1996 to 2000. 
the arithmetic average of the data from the 1999 and 2001 PNAD was considered. ${ }^{2}$

High salaries reduce FDI by raising production costs, which reduce the region's competitiveness. The same effect is produced by high taxes. To measure the production costs in each state, two variables were used, one related to the cost of labor and the other related to taxes.

The percentage of the cost of labor in the industry from the net income of firms was used as a proxy for the cost of labor. The data are from the Annual Industrial Survey (Pesquisa Industrial Anual) conducted by IBGE. All of the wages, income and social security contributions, compensations, benefits and other remuneration were summed up and divided by the net income of the company, resulting in the cost-of-labor to net-income ratio. In particular, the data from the 1996 survey were used for the year 1995 because the data from surveys prior to 1996 were not separated according to FU.

It is important to include information regarding taxes in the analysis due to different fiscal incentive policies promoted by different states, in the recent decades, in order to attract FDI. According to Nascimento (2008, p. 678), FU would have "future tax collection as a negotiating tool, usually ICMS for the states...". Because of the difficulty of obtaining accurate data from governing bodies, the proxy chosen to measure taxes was the state Goods and Services Tax (Imposto sobre Circulação de Mercadorias e Serviços - ICMS) revenue divided by the state GDP, resulting in a percentage tax burden on the state's economy - as an alternative measure for tax burden, regressions were estimated using state total taxes instead. Similarly to relative GDP, for each sampling year, the arithmetic average of the previous five years was calculated, including the base year. The data were obtained from the Institute of Applied Economic Research (Instituto de Pesquisa Econômica Aplicada - Ipea) website (Ipeadata).

A location with inadequate infrastructure increases production costs, discouraging FDI. Thus, the extension of the paved road network per thousand $\mathrm{km}^{2}$ was used as a proxy for the FU infrastructure. The

2 This procedure was adopted because the differences in sampling design between the 2000 Census and PNAD made comparisons between the indicators from both of the sources impossible. 
data on the road network were taken from the Statistical Yearbook of Land Transport (Anuário Estatístico dos Transportes Terrestres) on the National Land Transport Agency (Agência Nacional de Transportes Terrestres, ANTT) and Brazilian Transport Planning Agency (Empresa Brasileira de Planejamento de Transportes, GEIPOT) websites.

Table 1 contains a description of the explanatory variables used in this article, the expected sign of the coefficients and other papers in which these variables were used. In short, the main hypothesis to be tested in this study is that favorable structural conditions (measured here as human capital and infrastructure), a larger consumer market (measured as the three proxies for market size) and low production costs (measured as tax burden and cost of labor) attract a greater amount of foreign investment to states.

A regression model with panel data was used to study the effect of the explanatory variables on the FDI stock. According to Wooldridge (2002), a panel regression model is able to identify and measure effects that are not likely to be detected using cross-sectional or time-series analyses separately. The use of panel data is important as it enables the study of the same cross-section unit (in this case, each state of Brazil) over time (years 1995, 2000 and 2005), allowing researchers to detect the effect of the intrinsic and time-invariant heterogeneity of states, i.e., the fixed effect. Given the previous discussion, the investigation of the factors determining FDI location across different Brazilian states can be summarized according to Equation (1), as follows:

$\ln (F D I \text { per capita })_{i t}=\alpha+c_{i}+\beta_{1}$. market size ${ }_{i t}+\beta_{2}$. human capital hit $+\beta_{3 .}{\text { tax } \text { burden }_{i t}+\beta_{4 .} \text {.cost of labor }}_{i t}+\beta_{5}$. infrastructure ${ }_{i t}+\delta . z_{t}+u_{i t}$

The dependent variable is the natural logarithm of FDI stock per capita of state $i$ at year $t$, market size, illiteracy, taxes, cost of labor and infrastructure are the regressors (see Table l) for each state $i$ at time $t, z_{t}$ denotes year dummies (binary variables for each sampling year). $\alpha, \beta$ and $\delta$ are parameters, $c_{i}$ is the unobserved effect specific to each state (fixed effect), and $u_{i t}$ is the idiosyncratic error term. 
Table 1 - Description of the explanatory variables and their expected signs

\begin{tabular}{|c|c|c|c|}
\hline Explanatory variable & Proxy & $\begin{array}{c}\text { Expected } \\
\text { effect }\end{array}$ & Source \\
\hline \multirow{3}{*}{ Market size } & Population: number of inhabitants in the FU & \multirow{3}{*}{+} & \multirow{3}{*}{$\begin{array}{l}\text { Amal and Seabra, 2007; Broadman } \\
\text { and Sun, 1997; Cheng and Kwan, } \\
\text { 2000; Forssbaeck and Oxelheim, } \\
\text { 2008; Fung et al., 2002; Nonnenberg } \\
\text { and Mendonça, 2005; Nunnenkamp } \\
\text { and Spatz, 2002; Sun et al., 2002; } \\
\text { Hsiao and Shen, } 2003\end{array}$} \\
\hline & $\begin{array}{l}\text { Relative GDP: relative GDP of the FU in } \\
\text { relation to the country GDP }\end{array}$ & & \\
\hline & $\begin{array}{l}\text { Proximity to consumer market: dummy vari- } \\
\text { able which assumes } 1 \text { for the states of SP, } \\
M G \text { and RJ, } 0 \text { otherwise }\end{array}$ & & \\
\hline Human Capital & $\begin{array}{l}\text { Illiteracy rate: percentage of illiterate indi- } \\
\text { viduals aged } 15 \text { years and older in the FU }\end{array}$ & - & $\begin{array}{l}\text { Broadman and Sun, 1997; Hsiao and } \\
\text { Shen, 2003; Nonnenberg and Men- } \\
\text { donça, 2005; Nunnenkamp and Spatz, } \\
\text { 2002; Sun et al., } 2002\end{array}$ \\
\hline Tax burden & $\begin{array}{l}\text { Percentage ICMS revenue relatively to } \\
\text { GDP, by FU }\end{array}$ & - & Forssbaeck and Oxelheim, 2008 \\
\hline Cost of labor & $\begin{array}{l}\text { Percentage cost of labor in the industry in re- } \\
\text { lation to the net income of companies, by FU }\end{array}$ & - & $\begin{array}{l}\text { Euh \& Min (1986); Cheng and Kwan, } \\
\text { 2000; Forssbaeck and Oxelheim, } \\
\text { 2008; Hsiao and Shen, 2003; Sun et } \\
\text { al., } 2002\end{array}$ \\
\hline Infrastructure & $\begin{array}{l}\text { Extension of the paved road network per } \\
\text { thousand } \mathrm{km}^{2} \text {, by FU }\end{array}$ & + & $\begin{array}{l}\text { Broadman and Sun, 1997; Guimarães } \\
\text { et al., 2000; Hsiao and Shen, 2003; } \\
\text { Sun et al., } 2002\end{array}$ \\
\hline
\end{tabular}

Source: own authors.

Dummy variables were added to each year of the sample to control for the specific effects of each year which affect all of the federation units together - to avoid perfect multicollinearity, the year 1995 was removed from the estimations and therefore is the reference year. These variables are designed to control the effect of an increase or decrease in FDI on the Brazilian economy as a whole in a certain specified period, such as effects due to variation in the exchange rate, for instance. ${ }^{3}$

The Hausman ${ }^{4}$ test was used to decide on the use of fixed effects or random effects estimators. The random effects estimator should be

3 Several studies consider lagged FDI stock as one of the explanatory variables. For the database used in this study, this would mean using FDI stock from five years ago and, more importantly, would result in reducing the sample size by a third. Therefore, this variable was not included in the estimations, although it is important to emphasize that part of the agglomeration effect is expected to be captured by the three measures of market size.

4 The null hypothesis is that both random and fixed effects are consistent, but the first is efficient. The alternative hypothesis is that only the fixed effect estimator is consistent. The test statistic is distributed according to a $\chi^{2}$ distribution with $n$ degrees of freedom, where $n$ 
used under the Hausman test's null hypothesis, given this estimator generates efficient estimations by weighing the intra and inter-group (between) variation. Conversely, under the alternative hypothesis, only the fixed effects estimator is consistent. ${ }^{5}$

\section{Results}

\subsection{Descriptive Analysis}

The distribution of FDI stock per capita across the Brazilian states in 2005 is shown in Figure 1. The states were separated according to sample quartiles, which divided the Brazilian states into four FDI per capita groups: less than R 170.00 per capita, from $\mathrm{R} \$ 170.01$ to $\mathrm{R} \$ 696.00$, from $\mathrm{R} \$ 696.01$ to $\mathrm{R} \$ 1,556.00$ and more than $\mathrm{R} \$ 1,556.00$. There is a large discrepancy among the states, as the highest FDI per capita in 2005 were observed in Rio de Janeiro ( $\mathrm{R} \$ 12,396.67)$, São Paulo ( $\$$ \$ 8,500.03) and Mato Grosso ( $R \$ 3$,130.54), while the states of Paraíba ( $R$ \$ 6.90), Alagoas $(\mathrm{R} \$ 22.06)$ and Piauí ( $\mathrm{R} \$ 22.15)$ had the lowest FDI per capita values.

In order to provide a deeper depiction of the data, Table 2 shows the change in the explanatory variables in 2005 relatively to 1995 for the five Brazilian states with higher and lower FDI received in 2005. São Paulo, Rio de Janeiro, Espírito Santo, Paraná and Rio Grande do Sul, states belonging to the Southeast / South regions are those receiving the largest amount of FDI, especially for having large consumer markets in Brazil. In particular, Espírito Santo had a sharp decline of illiteracy, improving the quality of labor. In Rio de Janeiro, in turn, there was a significant fall in labor costs as well as an advance in infrastructure conditions. Substantial improvements in structural conditions were also observed in Parana and Rio Grande do Sul. On the other hand, the Brazilian states located in the Northeast were those receiving the lowest per capita FDI in 2005. In general, they exhi-

is the number of parameters estimated (except the constant).

5 The fixed effects estimator allows the unobserved effect to be correlated with the explanatory variables. As the within-group variation eliminates the unobserved effect for each sectional unit, every explanatory variable that is constant over time cannot be distinguished from the unobserved effect and thus, is eliminated as well. The random effects estimator, in turn, assumes a null correlation between the unobserved effect and the explanatory variables. 
bited an increase in taxes, especially Paraíba and Alagoas, with an increase of 36\% and 28\% from 1995 to 2005, respectively. Although they presented significant development in the infrastructure sector (except Alagoas), these states still have the lowest extension of the paved road network per thousand $\mathrm{km}^{2}$.

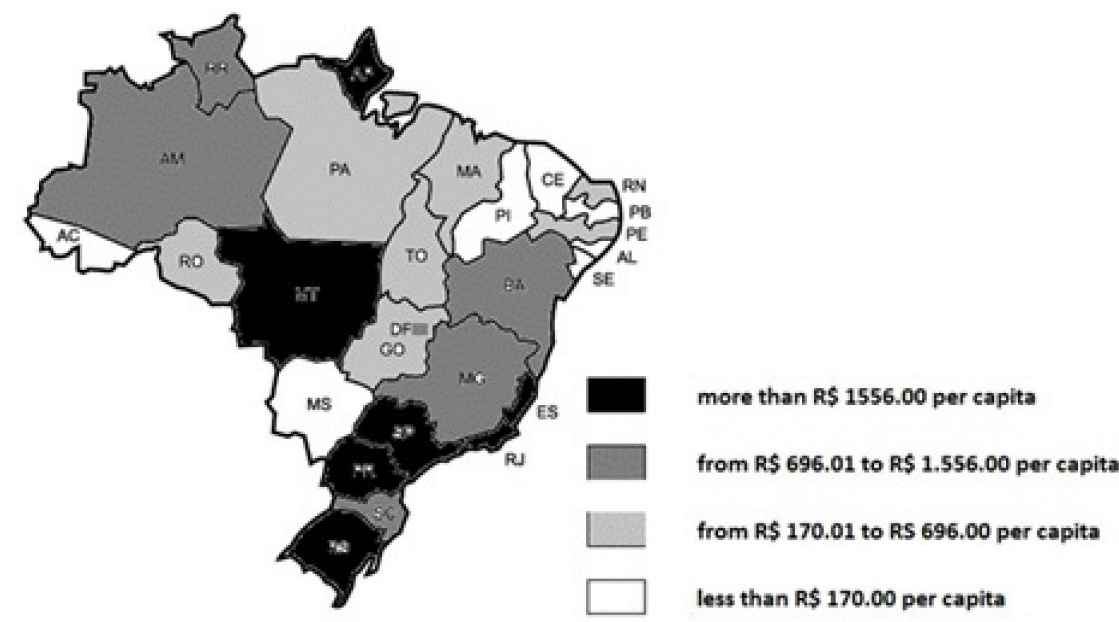

Figure 1 - Distribution of foreign direct investment across the Brazilian states in 2005

Source: own authors.

Table 2 - Percentage change in the explanatory variables in 2005 relatively to 1995

\begin{tabular}{cccccc}
\hline Highest FDI per capita & Population & Illiteracy & ICMS Taxes & Cost of labor & Paved road network \\
\hline SP & $20 \%$ & $-2 \%$ & $0 \%$ & $-9 \%$ & $23 \%$ \\
RJ & $16 \%$ & $-2 \%$ & $0 \%$ & $-12 \%$ & $18 \%$ \\
ES & $22 \%$ & $-5 \%$ & $1 \%$ & $-7 \%$ & $9 \%$ \\
PR & $18 \%$ & $-4 \%$ & $0 \%$ & $-5 \%$ & $40 \%$ \\
RS & $13 \%$ & $-3 \%$ & $1 \%$ & $-3 \%$ & $38 \%$ \\
\hline Lowest FDI per capita & Population & Illiteracy & ICMS Taxes & Cost of labor & Paved road network \\
\hline PI & $10 \%$ & $-8 \%$ & $15 \%$ & $-6 \%$ & $27 \%$ \\
CE & $21 \%$ & $-8 \%$ & $18 \%$ & $-3 \%$ & $34 \%$ \\
PB & $8 \%$ & $-7 \%$ & $36 \%$ & $-3 \%$ & $26 \%$ \\
AL & $12 \%$ & $-6 \%$ & $28 \%$ & $-1 \%$ & $3 \%$ \\
SE & $22 \%$ & $-6 \%$ & $18 \%$ & $-8 \%$ & $20 \%$ \\
\hline
\end{tabular}

Source: own authors. 
To describe the characteristics of the sample, the descriptive statistics of the data are shown in Table 3 . Besides the significant disparity of FDI among Brazilian states, other variables differed greatly across regions, the most pronounced differences observed in population size and GDP. For example, while São Paulo had over 40 million inhabitants in 2005, there were less than 400 thousand inhabitants in Roraima in the same year. Regarding relative GDP, in 2000, the state of São Paulo represented over 35\% of the country's GDP, while the sum of Roraima, Acre, Amapá, Tocantins and Rondônia accounted for only $1.1 \%$ for the same year.

Between 1995 and 2005, there was a 1 percentage point average increase in the tax burden, the illiteracy rate decreased about 4 percentage points, and the cost of labor also experienced an 8 percentage point average reduction in the period. The average state population exhibited significant growth, while the extension of the paved network showed a slight increase over the sample period. 
Table 3 - Descriptive statistics of the variables for the years 1995, 2000 and 2005

\begin{tabular}{|c|c|c|c|c|c|c|}
\hline Variable & Year & Average & Standard Deviation & Minimum & Maximum & Observations \\
\hline \multirow{4}{*}{ FDI per capita } & 1995 & $\mathrm{R} \$ 474.04$ & $\mathrm{R} \$ 779.92$ & $\mathrm{R} \$ 0.89$ & $\mathrm{R} \$ 3,146.10$ & 26 \\
\hline & 2000 & $\mathrm{R} \$ 821.74$ & $\mathrm{R} \$ 1,552.66$ & $R \$ 2.10$ & $\mathrm{R} \$ 7,207.18$ & 27 \\
\hline & 2005 & $\mathrm{R} \$ 1,552.76$ & $\mathrm{R} \$ 2,750.74$ & $\mathrm{R} \$ 6.90$ & $\mathrm{R} \$ 12,396.67$ & 27 \\
\hline & Total & $\mathrm{R} \$ 955.46$ & $\mathrm{R} \$ 1,918.46$ & $\mathrm{R} \$ 0.89$ & $\mathrm{R} \$ 12,396.67$ & 80 \\
\hline \multirow{4}{*}{ Population } & 1995 & $4,151,447$ & $3,866,473$ & 326,186 & $13,815,334$ & 27 \\
\hline & 2000 & $6,458,464$ & $4,820,847$ & $1,912,841$ & $19,237,450$ & 27 \\
\hline & 2005 & $8,271,783$ & $11,366,186$ & 262,194 & $40,442,795$ & 27 \\
\hline & Total & $6,293,898$ & $7,568,172$ & 262,194 & $40,442,795$ & 81 \\
\hline \multirow{4}{*}{ Relative GDP } & 1995 & $3.7 \%$ & $7.0 \%$ & $0.1 \%$ & $34.9 \%$ & 27 \\
\hline & 2000 & $3.7 \%$ & $7.0 \%$ & $0.1 \%$ & $35.2 \%$ & 27 \\
\hline & 2005 & $3.7 \%$ & $6.7 \%$ & $0.1 \%$ & $33.8 \%$ & 27 \\
\hline & Total & $3.7 \%$ & $6.8 \%$ & $0.1 \%$ & $35.2 \%$ & 81 \\
\hline \multirow{4}{*}{ Illiteracy } & 1995 & $18.2 \%$ & $10.1 \%$ & $6.5 \%$ & $35.1 \%$ & 27 \\
\hline & 2000 & $17.1 \%$ & $8.6 \%$ & $5.7 \%$ & $33.4 \%$ & 27 \\
\hline & 2005 & $13.9 \%$ & $7.8 \%$ & $4.7 \%$ & $29.3 \%$ & 27 \\
\hline & Total & $16.4 \%$ & $8.9 \%$ & $4.7 \%$ & $35.1 \%$ & 81 \\
\hline \multirow{4}{*}{ ICMS Taxes } & 1995 & $6.5 \%$ & $1.8 \%$ & $3.2 \%$ & $10.0 \%$ & 27 \\
\hline & 2000 & $7.0 \%$ & $1.5 \%$ & $4.2 \%$ & $9.6 \%$ & 27 \\
\hline & 2005 & $7.4 \%$ & $1.4 \%$ & $3.8 \%$ & $9.5 \%$ & 27 \\
\hline & Total & $7.0 \%$ & $1.6 \%$ & $3.2 \%$ & $10.0 \%$ & 81 \\
\hline \multirow{4}{*}{ Cost of labor } & 1995 & $20.5 \%$ & $8.8 \%$ & $8.0 \%$ & $43.1 \%$ & 27 \\
\hline & 2000 & $14.6 \%$ & $5.9 \%$ & $6.1 \%$ & $30.7 \%$ & 27 \\
\hline & 2005 & $12.3 \%$ & $5.4 \%$ & $5.8 \%$ & $27.6 \%$ & 27 \\
\hline & Total & $15.8 \%$ & $7.6 \%$ & $5.8 \%$ & $43.1 \%$ & 81 \\
\hline \multirow{4}{*}{ Infrastructure } & 1995 & 44.72 & 38.66 & 0.87 & 127.54 & 27 \\
\hline & 2000 & 43.78 & 39.25 & 1.09 & 127.54 & 27 \\
\hline & 2005 & 50.55 & 44.98 & 1.04 & 151.21 & 27 \\
\hline & Total & 44.92 & 40.65 & 0.87 & 151.21 & 81 \\
\hline
\end{tabular}

Source: own authors. 


\subsection{Econometric Analysis}

In order to provide a preliminary evaluation, Equation (1) was estimated cross-sectionally for each of the three sample years, whose results are presented in Table 4. As previously discussed, to capture the effect of market size, the model was estimated considering each of the three proxies separately, i.e., the natural logarithm of population size, relative GDP of the state and the "proximity to consumer market" dummy. Standard deviations are reported in parenthesis and asterisks denote statistical significance at ${ }^{*}=10 \%,{ }^{* *}=5 \%$ and ${ }^{* * *}=1 \%$ levels $^{6}$.

According to the results, the three measures of market size exert a positive effect on the amount of FDI received by each Brazilian state. However, except the case of population size, the decrease in the magnitude of the parameters over time suggests a decreasing importance of market scale in attracting FDI. For state relative GDP and proximity to market dummy, the parameters for 2005 is about half of those estimated for 1995.

The coefficients regarding the illiteracy rate are negative in all the estimations, which indicate that a more qualified workforce (lower proportion of illiterate people) tends to attract FDI - in particular, these coefficients are statistically significant in 2000 and 2005. Higher production costs, in turn, are likely to cause a negative effect on the amount of foreign investment received by each Brazilian state, given the coefficients regarding ICMS tax revenues ${ }^{7}$ and cost of labor are generally negative - however, in some years (especially in 2005), the parameters do not exhibit statistic significance at the usually accepted levels. Finally, for the case of infrastructure, the extension of the paved road network seems to attract foreign investment as the coefficients generally exhibit a positive sign - however, the parameter is statistically significant only in the case of relative GDP and dummy for market proximity in 2000. In a general overview, even though the small number of observations produces high standard deviations and consequently low statistic significance, the cross-section results are similar to those found by Sun, Tong \& Yu (2002), Forssbaeck \& Oxelheim (2008) and Cheng \& Kwan (2000), for instance, as discussed in the literature review. In this sense, there

${ }^{6}$ Data regarding FDI received by Rondônia in 1995 is not reported by the CCEP, which explains why regressions for this year comprise 26 observations.

7 Results are similar when total taxes are used as proxy for tax burden - see Appendix A.1. 
is evidence that market scale, lower production costs and qualified labor force are important factors that explain the distribution of FDI across regions of a given country, similarly to the international evidence.

As an a alternative approach, which follows the motivation provided by Figure 1, Equation (1) was also estimated using quantile regressions - in particular, we performed pooled estimations for the quantiles $0.25,0.50$ and 0.75 . According to the results presented in Table 5, it is possible to observe that the coefficients exhibit some degree of variation across the three quantiles but preserve the signal, i.e., the direction of the influence of each explanatory variable seems not to vary over the distribution. In particular, the three measures of market size exert a positive effect on the amount of FDI received by Brazilian states - all the parameters exhibit statistic significance, except total population and relative GDP for the 0.75 quantile estimations. Reinforcing the cross-section results, illiteracy rate exerts a negative influence on the amount of FDI received, as the coefficients are negative and statistically significant in all the estimations. Results regarding ICMS taxes, labor costs and infrastructure conditions are similar to the results presented in Table 4, although the statistic significance varies according to the quantiles: it is possible to observe that ICMS taxes are statistically significant only for the 0.25 quantile estimations. Labor costs, in turn, do not exhibit significance whenever total population is considered as a proxy for market size. 


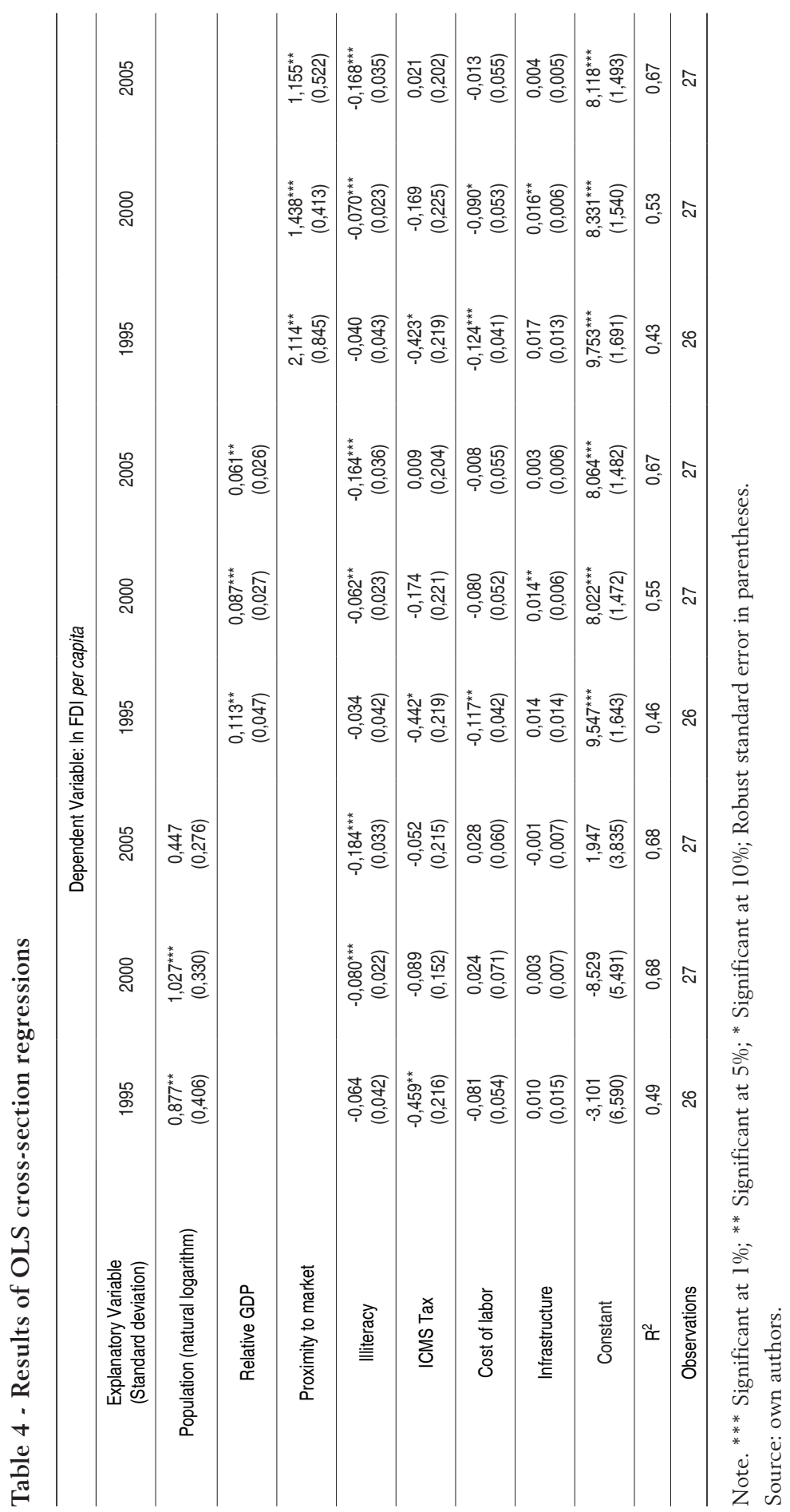

Est. Econ., São Paulo, vol. 43, n.2, p. 241-269, abr-jun. 2013 


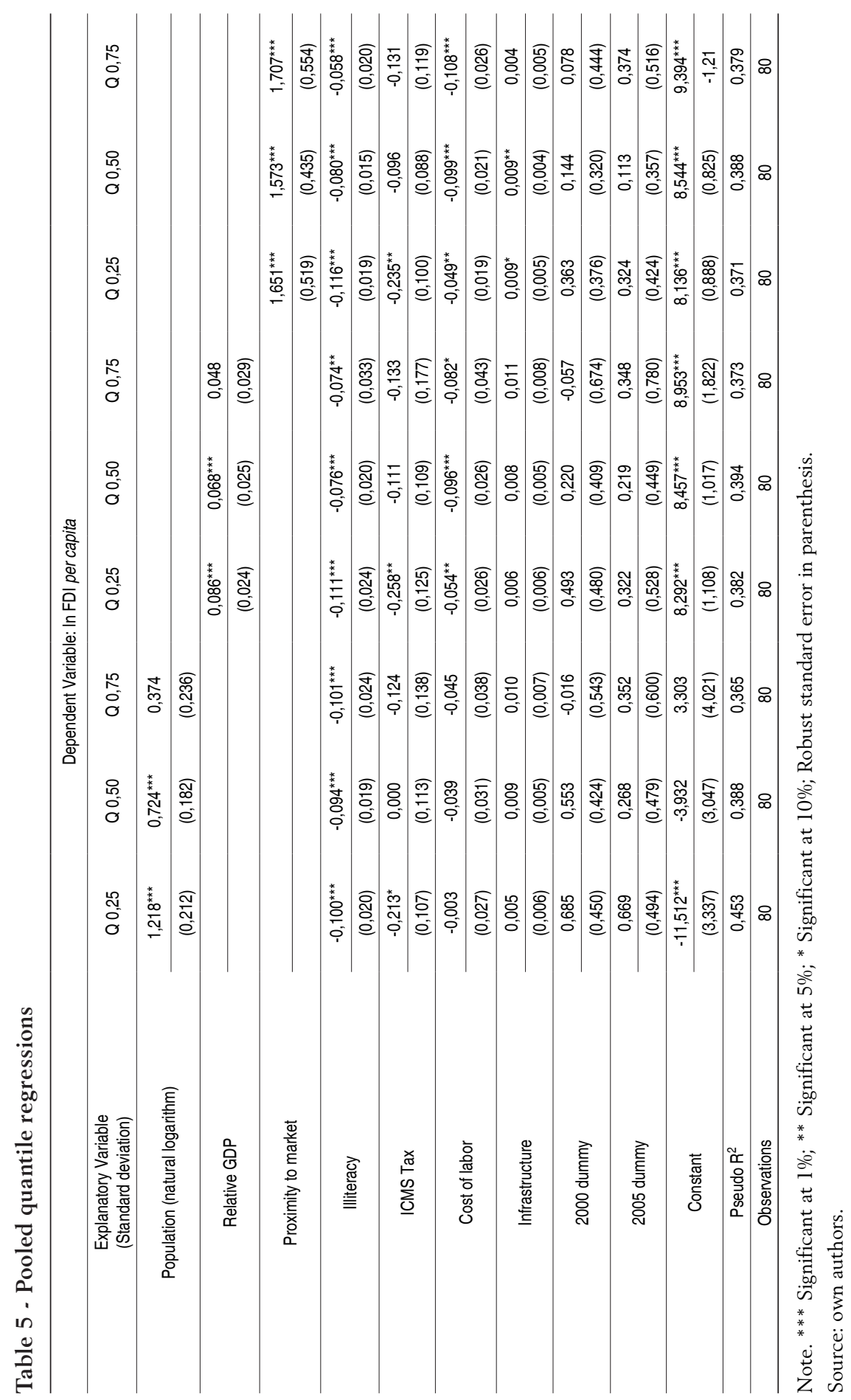


Finally, panel data results based on the random effects estimation are shown in Table 6 - results of the fixed effects estimation are shown in Appendix A.2. According to the Hausman test, the random effects estimators were consistent and efficient and therefore were chosen for the analysis of results. Based on the model results, the consumer market size was statistically significant for explaining the FDI distribution across Brazilian FU in the three estimated models. As expected, the coefficient sign was positive, suggesting that an increase in the local market size causes an increase in the FDI per capita received by states.

The quality of human capital was also statistically significant for explaining the foreign investment flow in the three estimations. According to the literature and the previous results, the higher the quality of human capital, the greater the amount of investment received. Because the proxy used in this study was the illiteracy rate among individuals aged 15 years and older (an inverse measurement of quality of human capital), the signs are negative, as expected.

For production costs, measured as the ICMS tax rate and cost of labor, almost all of the coefficients were statistically significant: taxes were relevant in all the models and the cost of labor was relevant in the models using relative GDP and the "proximity to consumer market" dummy. Moreover, the coefficients of these two proxies had negative signs, supporting the perception that an increase in production costs would reduce the FDI per capita in FU. Results are practically the same when state total taxes are used as proxy for tax burden (Appendix A.3).

The coefficient of the variable extension of paved network exhibited the expected sign, indicating that states with better infrastructure attract more resources - however, the parameter was statistically significant only in column C. Finally, the indicator dummies for the years 2000 and 2005, used as control variables to explain a possible increase of FDI over time that was not caused by explanatory variables, were not statistically significant.

To more specifically analyze the resulting estimates in Table 6 , the marginal effects of each regressor on the variation of FDI stock per capita were calculated. The analysis of the marginal effects of market size indicated that a $1 \%$ increase in the population of the FU caused a $0.7 \%$ average increase in the received investment per capita, 
with all of the other variables held constant (model A). Moreover, a $1 \%$ increase in the state relative GDP results in a 9\% average increase in the FDI per capita in the state (model B). Finally, if the $\mathrm{FU}$ is close to the consumer market (SP, RJ and MG), an expected $160 \%$ increase in FDI per capita should be observed, ceteris paribus (model C).

Selecting model B and following the same reasoning, a 1\% reduction in the illiteracy rate in the FU causes an expected increase of at least $7 \%$ in the FDI per capita, while a $1 \%$ reduction in the tax burden leads to an increase of approximately $25 \%$ in the FDI per capita. Moreover, a $1 \%$ reduction in the cost of labor results in an expected $8 \%$ increase in the FDI per capita, while improving infrastructure by increasing the extension of the paved network by one $\mathrm{km}$ per thousand $\mathrm{km}^{2}$ results in an expected increase of approximately $0.9 \%$ in the FDI per capita in the FU, with all of the other variables held constant.

Table 6 - Results of the panel data regression with random effects

\begin{tabular}{|c|c|c|c|}
\hline \multicolumn{4}{|c|}{ Dependent Variable: In FDI per capita } \\
\hline $\begin{array}{l}\text { Explanatory Variable } \\
\text { (Standard deviation) }\end{array}$ & (A) & (B) & (C) \\
\hline Population (natural logarithm) & $\begin{array}{l}0,696^{\star \star *} \\
(0,222)\end{array}$ & & \\
\hline Relative GDP & & $\begin{array}{l}0,090^{\star \star \star} \\
(0,023)\end{array}$ & \\
\hline Proximity to market & & & $\begin{array}{l}1,589^{* * *} \\
(0,420)\end{array}$ \\
\hline Illiteracy & $\begin{array}{l}-0,095^{\star \star *} \\
(0,026)\end{array}$ & $\begin{array}{l}-0,071^{\star \star} \\
(0,029)\end{array}$ & $\begin{array}{c}-0,077^{\star \star \star} \\
(0,029)\end{array}$ \\
\hline ICMS Tax & $\begin{array}{l}-0,245^{\star *} \\
(0,118)\end{array}$ & $\begin{array}{l}-0,255^{\star *} \\
(0,130)\end{array}$ & $\begin{array}{l}-0,249^{*} \\
(0,131)\end{array}$ \\
\hline Cost of labor & $\begin{array}{l}-0,038 \\
(0,036)\end{array}$ & $\begin{array}{c}-0,080^{\star \star \star} \\
(0,029)\end{array}$ & $\begin{array}{c}-0,087^{\star \star \star} \\
(0,029)\end{array}$ \\
\hline Infrastructure & $\begin{array}{c}0,005 \\
(0,006)\end{array}$ & $\begin{array}{c}0,009 \\
(0,006)\end{array}$ & $\begin{array}{l}0,011^{*} \\
(0,006)\end{array}$ \\
\hline 2000 dummy & $\begin{array}{c}0,501 \\
(0,440)\end{array}$ & $\begin{array}{c}0,329 \\
(0,413)\end{array}$ & $\begin{array}{c}0,272 \\
(0,409)\end{array}$ \\
\hline 2005 dummy & $\begin{array}{c}0,726 \\
(0,533)\end{array}$ & $\begin{array}{c}0,578 \\
(0,501)\end{array}$ & $\begin{array}{c}0,469 \\
(0,489)\end{array}$ \\
\hline Constant & $\begin{array}{l}-1,864 \\
(3,793)\end{array}$ & $\begin{array}{l}8,591^{* \star *} \\
(1,174)\end{array}$ & $\begin{array}{c}8,864^{* \star *} \\
(1,195)\end{array}$ \\
\hline $\mathrm{R}^{2}$ & 0,563 & 0,529 & 0,516 \\
\hline Observations & 80 & 80 & 80 \\
\hline Hausman test (p-value) & 0,669 & 0,991 & 0,981 \\
\hline
\end{tabular}

Note. ${ }^{* *}$ Significant at $1 \% ;{ }^{*}$ Significant at 5\%; ${ }^{*}$ Significant at $10 \%$; Robust standard error in Source: own authors. 


\section{Conclusion}

This study used panel data to analyze the determinants of FDI distribution across the 27 federation units in Brazil. By using data from the Census of Foreign Capitals in the Country for the years of 1995, 2000 and 2005, cross-section, quantile and panel data regressions results suggest that market size, quality of the workforce and infrastructure are important factors that explain the highly heterogeneous distribution of FDI across Brazilian states. Conversely, high costs of labor and high tax burden are factors that reduce foreign direct investment.

A primary contribution of this paper concerns the research itself, given the recent literature on this subject has focused on investigations of the determinants for the regional allocation of foreign investment in a particular country - this focus is particularly valid for the Brazilian case, given the country has received a large amount of FDI over the last years, but has significant regional disparities over its territory. In a comparative perspective, our results are consistent with the evidence provided by the international literature and support the empirical results of previous studies that examined the determinants of FDI distribution across regions of a given country.

Second, the results are important for the process of policy formulation because they reinforce the perception that states aiming at attracting foreign investment should be concerned not only with granting tax benefits, but promoting the qualifications of the workforce as well as providing high quality infrastructure. Payroll tax reductions would also be desirable as labor costs have also affected investment decisions by multinational companies. Given that labor tax and contribution rates are under the control of Federal legislation (i.e., are not defined by each Brazilian state separately), the so claimed labor legislation reform could possibly benefit Brazilian states when receiving foreign investments. Anyhow, in the present context, as the richest and more developed regions are receiving larger amount of FDI relatively to poor and less developed states, the social and economic heterogeneity across Brazilian areas are likely to persist, ceteris paribus. 


\section{References}

AMAL, M., \& SEABRA, F. Determinantes do investimento direto externo (IDE) na América Latina: uma perspectiva institucional. Revista Economia, 8(2), 231-247, 2007.

Banco Central do Brasil. N.d. Censo de capitais estrangeiros no país. http://www. bcb.gov. br/?CENSOCE. [Online; accessed 16-Nov-2009].

BEVAN, A. A., \& ESTRIN, S. The determinants of foreign direct investment into European transition economies. Journal of Comparative Economics, 32(4), 775-787, 2004.

BLONIGEN, B. A., DAVIES, R. B. \& HEAD, K. Estimating the knowledge-capital model of the multinational enterprise: comment. American Economic Review 93(3):980- 994, 2003.

BROADMAN, H. G., \& SUN, X. The distribution of foreign direct investment in China. The World Economy, 20(3), 339-361, 1997.

BUCKLEY, P. J., \& CASSON, M. The future of the multinational enterprise (Vol. 1). London: Macmillan, 1976.

BUCKLEY, P. J., \& CASSON, M. The optimal timing of a foreign direct investment. The Economic Journal, 91(361), 75-87, 1981.

CHAKRABARTI, A. A theory of the spatial distribution of foreign direct investment. International Review of Economics \& Finance, 12(2), 149-169, 2003.

CHENG, L. K., \& KWAN, Y. K. What are the determinants of the location of foreign direct investment? The Chinese experience. Journal of International Economics, 51(2), 379-400, 2000.

COUGHLIN, C. C., TERZA, J. V., \& ARROMDEE, V. State characteristics and the location of foreign direct investment within the United States. The Review of Economics and Statistics, 675-683, 1991.

DU, J., LU, Y., \& TAO, Z. FDI location choice: agglomeration vs institutions. International Journal of Finance \& Economics, 13(1), 92-107, 2008.

DUNNING, J. H. Explaining the international direct investment position of countries: towards a dynamic or developmental approach. Weltwirtschaftliches Archiv, 117(1), 30-64, 1981.

FERNANDES, E. A. \& CAMPOS, A. C. Investimento direto estrangeiro e o desempenho das exportações brasileiras. Revista de Economia Política 28(3):490-509, 2008.

FORSSBÆCK, J., \& OXELHEIM, L. Financial Determinants of Foreign Direct Investment. Stockholm: Research Institute of Industrial Economics, 2008.

FUNG, K. C., IIZAKA, H., \& PARKER, S. Determinants of US and Japanese direct investment in China. Journal of Comparative Economics, 30(3), 567-578, 2002.

GUIMARAES, P., FIGUEIREDO, O., \& WOODWARD, D. Agglomeration and the location of foreign direct investment in Portugal. Journal of Urban Economics, 47(1), 115-135, 2000.

HSIAO, C., \& SHEN, Y. Foreign Direct Investment and Economic Growth: The Importance of Institutions and Urbanization*. Economic development and Cultural change, 51(4), 883-896, 2003.

HYMER, S. H. The international operations of national firms: a study of direct foreign investment Phd thesis Cambridge: MIT, 1960.

KONRAD, K.A., \& KOVENOCK, D. Competition for FDI with vintage investment and agglomeration advantages. Journal of International Economics, 79(2), 230-237, 2009.

LAPLANE, M., \& SARTI, F. Investimento direto estrangeiro e a retomada do crescimento sustentado nos anos 90. Economia e sociedade, 8, 143-181, 1997.

MATTOS, L. B. DE, CASSUCE, F. C. DA C. \& CAMPOS, A. C. Determinantes dos investimentos diretos estrangeiros no Brasil, 1980-2004. Revista de Economia Contemporânea 11:39 - 60, 2007.

MOOSA, I. A. Foreign direct investment: theory, evidence, and practice. New York: Palgrave Macmillan, 2002.

Est. Econ., São Paulo, vol. 43, n.2, p. 241-269, abr.jun. 2013

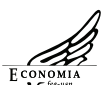


NASCIMENTO, S. P. Guerra fiscal: uma avaliação comparativa entre alguns estados participantes. Revista Economia 12(4): 677-706, 2008.

NONNENBERG, M. J. B. \& MENDONÇA, M. J. C. Determinantes dos investimentos diretos externos em países em desenvolvimento. Estudos Econômicos 35(4):631-655, 2005.

NUNNENKAMP, P. \& SPATZ, J. Determinants of FDI in developing countries: has globalization changed the rules of the game? Transnational Corporations 11(2):1- 34, 2002.

OHLIN, B. Interregional and international trade. Cambridge: Harvard University Press, 1933.

RASCIUTE, S. \& PENTECOST, E. J. A Nested logit approach to modeling the location of foreign direct investment in the Central and European Countries. Economic Modeling 27(1):32-39, 2010.

SILVA, O. M., ALMEIDA, F. M., \& OLIVEIRA, B. M. Comércio internacional x intranacional no Brasil: medindo o efeito-fronteira. Nova Economia 17(3):427-439, 2007.

STEIN, E. \& DAUDE, C. Longitude matters: time zones and the location of foreign direct investment. Journal of International Economics 71:96-112, 2007.

SUN, Q., TONG, W., \& YU, Q. Determinants of foreign direct investment across China. Journal of International Money and Finance 21(1):79-113, 2002.

VERNON, R. International Investment and International Trade in the Product Cycle. The Quarterly Journal of Economics 80(2):190-207, 1966.

YOON-DAE, E., \& SANG, H. Foreign direct investment from developing countries: the case of Korean firms. The Developing Economies, 24(2), 149-168, 1986. 


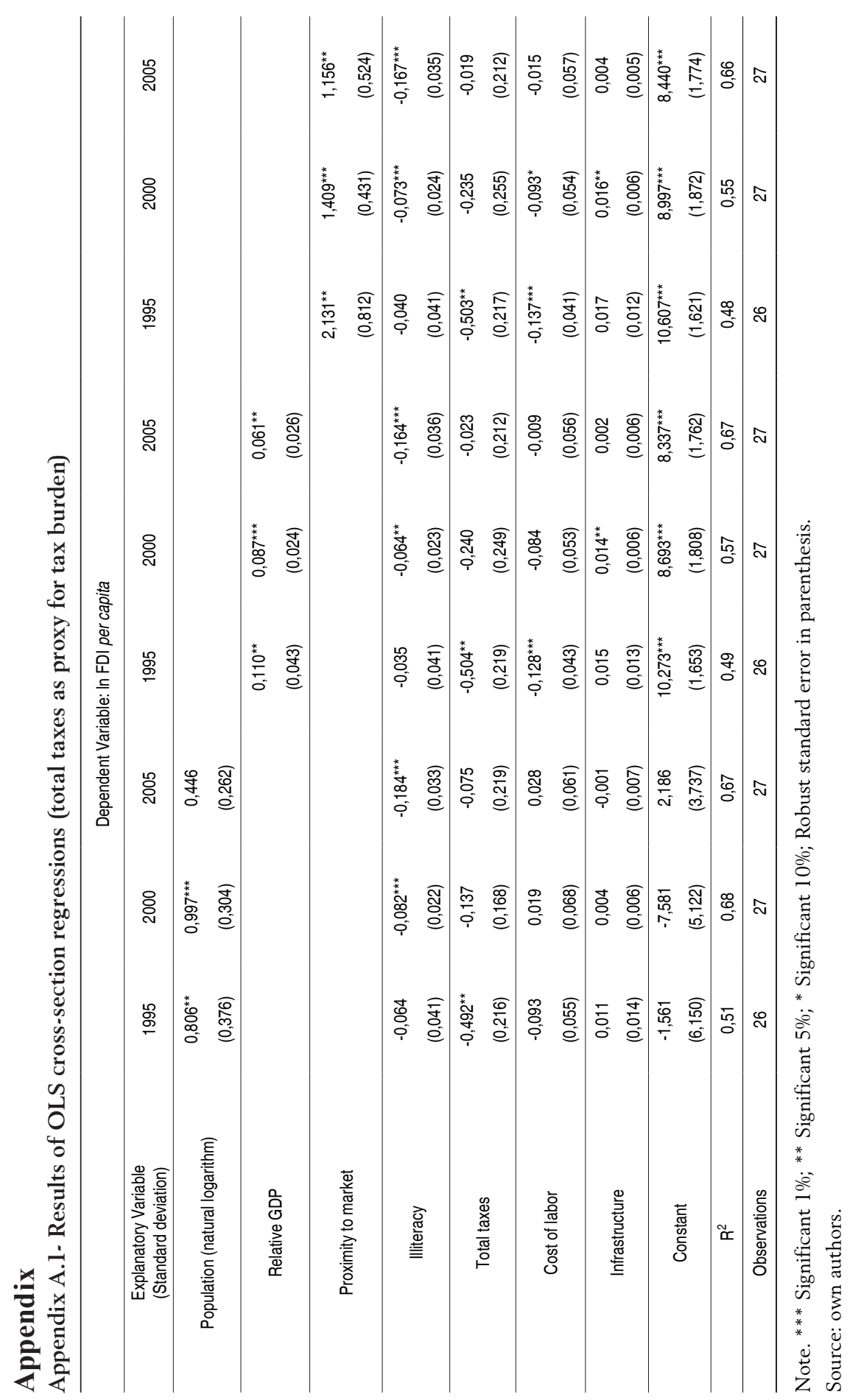


Appendix A.2 - Results of panel data regression with fixed effects

\begin{tabular}{cccc}
\hline \multicolumn{5}{c}{ Dependent Variable: In FDI per capita } & \\
\hline $\begin{array}{c}\text { Explanatory Variable } \\
\text { (Standard deviation) }\end{array}$ & $(\mathrm{A})$ & $(\mathrm{B})$ & $(\mathrm{C})$ \\
\hline Population (natural logarithm) & 1,491 & & \\
\hline Relative GDP & $(3,943)$ & & \\
& & 0,412 & - \\
\hline Proximity to market & & $(0,280)$ & $-0,038$ \\
\hline \multirow{2}{*}{ Illiteracy } & & & $(0,084)$ \\
\hline \multirow{2}{*}{ ICMS Tax } & $-0,050$ & $-0,035$ & $-0,409^{*}$ \\
& $(0,107)$ & $(0,084)$ & $(0,226)$ \\
\hline \multirow{2}{*}{ Cost of labor } & $-0,405^{*}$ & $-0,378$ & $-0,087$ \\
& $(0,222)$ & $(0,227)$ & $(0,055)$ \\
\hline \multirow{2}{*}{ Infrastructure } & $-0,080$ & $-0,085$ & 0,011 \\
& $(0,054)$ & $(0,056)$ & $(0,030)$ \\
\hline \multirow{2}{*}{2000 dummy } & 0,015 & 0,011 & 0,380 \\
& $(0,038)$ & $(0,030)$ & $(0,618)$ \\
\hline \multirow{2}{*}{2005 dummy } & 0,231 & 0,379 & 0,769 \\
& $(0,858)$ & $(0,621)$ & $(1,058)$ \\
\hline \multirow{2}{*}{ Constant } & 0,418 & 0,767 & $9,388^{* * *}$ \\
\hline \multirow{2}{*}{$R^{2}$} & $(1,728)$ & $(1,057)$ & $(2,395)$ \\
\hline \multirow{2}{*}{ Observations } & $-13,101$ & $7,548^{* *}$ & 0,321 \\
\hline
\end{tabular}

Note. ${ }^{* *}$ Significant at $1 \%$; ${ }^{* *}$ Significant at $5 \%$; Significant at $10 \%$; Robust standard error in parenthesis.

Source: own authors. 


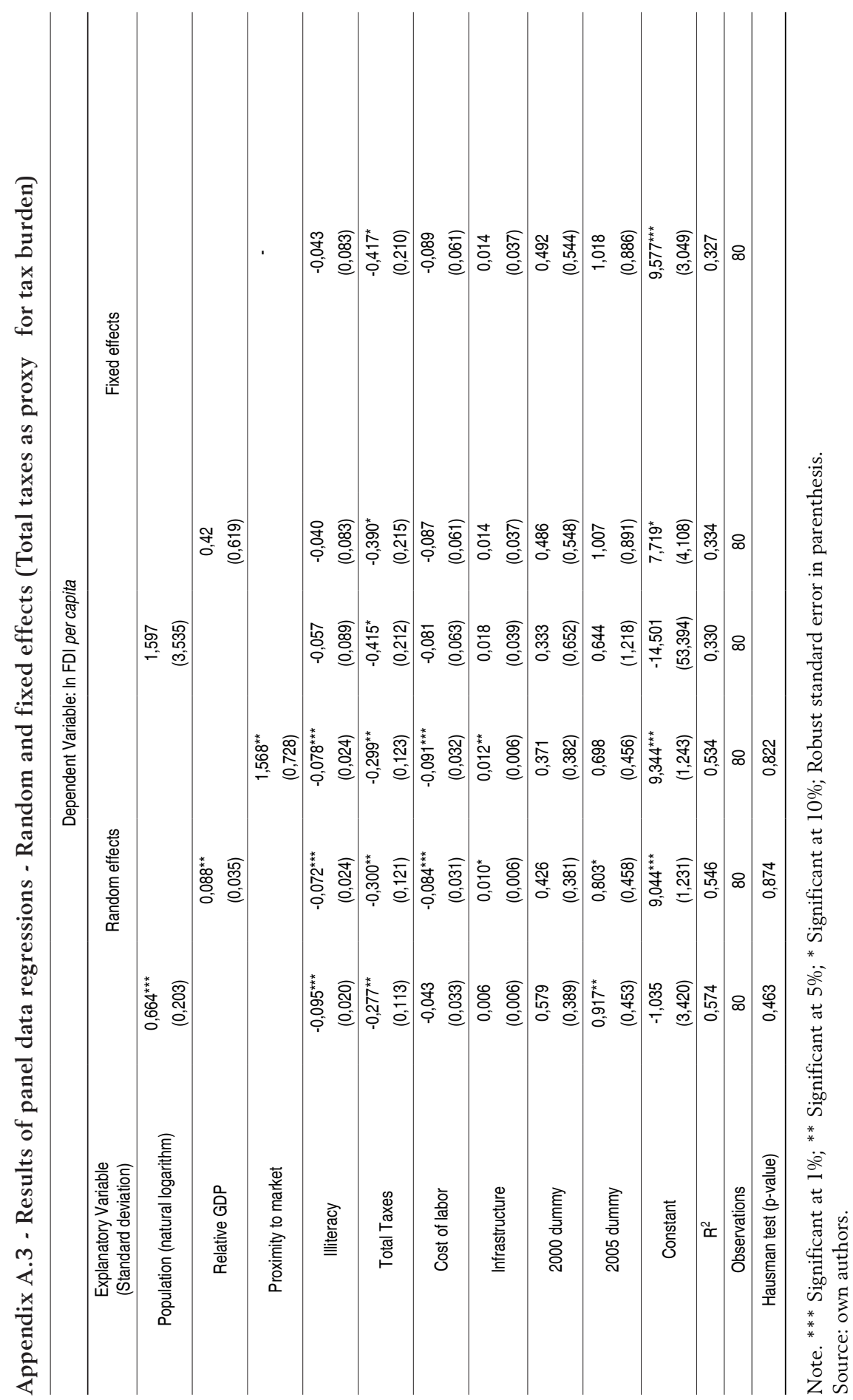

